\title{
Foam fractionation in recovery of captopril
}

\author{
Avishek Mandal1
}

\begin{abstract}
Toxic effect caused due to the presence of pharmaceuticals in waste water has been recognized as one of the emerging issue in the presentday environmental pollution. The aim of the present work is to investigate the feasibility of foam fractionation technique in batch mode for the recovery of captopril from dilute aqueous solution and to compare the performance of drug recovery from two feed solutions, one containing pure drug and the other containing formulated drug (tablet). Captopril is an anionic compound used as antihypertensive drug. Presence of this drug can cause aquatic toxicity. The performance of recovery was investigated as a function of gas velocity, $\mathrm{pH}$ of feed solution, collector-colligend ratio (j), colligend (drug) concentration, feed volume, column height and aliphatic chain length of the collector (surface active agent) and finally, optimum condition had been determined. Percentage recovery was enhanced to $90 \%$ (approx) for pure drug at the optimum $\mathrm{pH}$ value of $3.75, j=4$ at an optimum gas velocity. The optimum gas velocity depends on feed volume. Percentage recovery $(\mathrm{Rp})$ decreases with increase of chain length. Enrichment ratio (Er) was enhanced with the increase of foam height in the column. Rp and Er were found lower in formulated type of captopril in comparison to the pure drug due to the presence of other soluble ingredients in tablet.
\end{abstract}

KEY WORDS: Foam fractionation; captopril; collector-colligend ratio; percentage recovery; enrichment ratio

\section{INTRODUCTION}

Captopril itself is relatively stable at temperatures up to $50^{\circ}$, and freely water-soluble anionic compound (1). Captopril is a sulfhydryl containing dipeptide surrogate of proline. Captopril is the first orally active inhibitor of ACE. It is used in the treatment of severe essential and renovascular hypertension, where other therapy has failed, and congestive heart failure (2).

Foam fractionation is the foaming off of dissolved material from a solution via adsorption at the bubble surfaces. All methods of separation, whether physical or chemical, are based on differences in properties. The foam fractionation technique is based on the difference in surface activity. The surface active material, which may be molecular, colloidal, or macro particulate in size, is selectively adsorbed or attached at the surfaces of bubbles rising through the liquid, and is thereby concentrated or separated. A substance that is not surface active itself can sometimes be made effectively surface active through the deliberate addition, or presence otherwise, of a suitable surfactant (termed the collector), which will combine with the substance in question (termed the colligend) so that it may be adsorbed (3).

Foam fractionation applies a simple apparatus and causes only little investment, energy and running costs $(4,5)$. Foam fractionation devices can be run in a number of different modes: batch
AFFILIATIONS

1Jadavpur University,

Pharmaceutical Engineering, Kolkata, Hindistan

CORRESPONDENCE

Avishek Mandal

E-mail:

avishek7477@gmail.com

Received:

15.05.2013

Revision:

29.07.2013

Accepted:

01.08.2013 
or continuous flow, with or without reflux of the collapsed foamate, with or without multiple staging, with feed to a pool at the bottom of the column, or with feed into the rising foam (6). Foam fractionation technique is especially effective for the separation of materials at low concentrations. Practically, foam is nevertheless formed in the micelle region and separations can be successfully carried out; however, better separation would occur below the CMC. Many factors affect the performance and efficiency of a foam separation system, the relative importance of each depending on the specific conditions (7).

The application of foam fractionation to biological materials, such as proteins, enzyme etc., is very much attractive (8-10). Surfactants represent a striking problem in water resources. Foam fractionation enables both defoaming and concentration of surfactants (11). Foam fractionation technique is important for the recovery of penicillin $G$ at low concentration levels from aqueous solutions (12).

The fate of pharmaceuticals in aquatic environment has been recognized as one of the emerging issue in the environmental sciences. Presence of captopril can cause aquatic toxicity (13). In this study, the effects of some of the important parameters in foam fractionation (such as gas velocity, $\mathrm{pH}$ of feed solution, collector-colligend ratio, colligend concentration, feed volume, column height and aliphatic chain length of the collector) on the recovery of captopril were determined.

\section{MATERIALS AND METHODS}

\subsection{Materials}

Captopril (gifted by Wockhardt limited, Mumbai) was used throughout this research and Tablet Aceten (25 mg.) was purchased from local medicine shop. tetradecyltrimethylammonium bromide (TTAB) (E. Merck India Limited), and hexadecyltrimethylammonium bromide (CTAB) (Loba Chemie, Bombay) were used as collectors. Other chemicals and reagents used were analytical reagent grade. For all experiments, double-distilled water was used.

\subsection{Foam fractionation}

A schematic diagram of the apparatus used for batch process is shown in Figure 1. A foam fractionation apparatus was uniquely designed and set up with glass works from glass blowing and supplements such as a gas cylinder for nitrogen supply and a flowmeter purchased from suppliers.

Glass column with an internal diameter $4.2 \mathrm{~cm}$ and length 65 $\mathrm{cm}$ was used in this study. The drug solution was contacted with the gas bubble rising from the frit (No. 3) fitted at the bottom of the column. The separation performance is referred to as the enrichment ratio $\left(\mathrm{E}_{\mathrm{r}}\right)$ and percentage recovery $\left(\mathrm{R}_{\mathrm{p}}\right)$ of captopril; the $E_{r}$ is the ratio of drug concentration in foamate versus the drug concentration in the initial feed solution, and $R_{p}$ is the percentage of the ratio of amount of drug in foamate and the amount of drug in the initial feed solution. A feed solution of desired concentration was prepared by dissolving pure drug with subsequent addition of required amount of surface-active agent. Formulated drug (tablet) was dissolved in sufficient amount of water in a conical flask and then solubilized the drug by the help of Ultrasonic cleaning bath for 15 minutes, then filter the solution with the help of whatman filter paper \& then prepared the feed solution of desired concentration by dissolving surfactant. All the experiments were

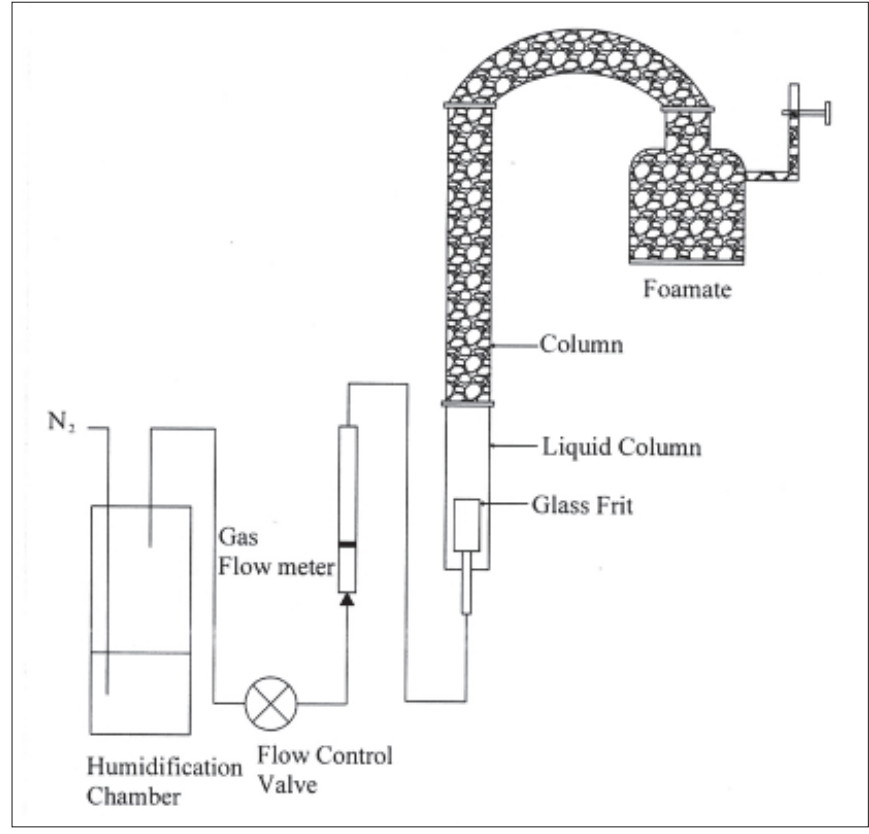

FIGURE 1. Schematic diagram of foam fractionation apparatus.

batch type. The feed solution were adjusted to the desired $\mathrm{pH}$ by using either by using either $0.1 \mathrm{M} \mathrm{NaOH}$ or $0.1 \mathrm{M} \mathrm{HCL}$ and then transferred to the column. Nitrogen gas was passed through the bottom of the column via a gas flowmeter and a humidifier. The surfactant form stable foam and drug was adsorbed on the foam-bubble interface. The foam was allowed to overflow the top of the column into a container and collapse into a small volume that is enriched with the drug. The concentration of initial feed solution and the residual solution and foamate (collapsed foam) were determined by the titrimetric assay method. All the experiments were performed in triplicate at room temperature and under atmospheric pressure.

\subsection{Analytical methods}

Samples of the initial feed solution, of the foamate, as well as of the residual solution (for controlling purposes) were taken to determine the concentration of the drug. It was measured by the titrimetric assay method using starch solution as indicator (14).

\section{Calculation}

The enrichment ratio $\left(E_{r}\right)$ and percentage recovery $\left(R_{p}\right)$ were calculated by the following equations:

Enrichment ratio $\left(E_{r}\right)=$ Concentration of drug in the foam $\left(C_{f}\right) /$ Concentration of drug in the feed $\left(\mathrm{C}_{\mathrm{i}}\right)$

and

Percentage recovery $\left(R_{p}\right)=($ Mass of drug in the foam $/$ Mass of drug in the feed) $x 100$

\section{RESULTS AND DISCUSSION}

Since Captopril cannot be enriched in the foam, collectors are needed. Two collectors with different chain length were used:

Figure 2 (Table 1) shows the effect of superficial gas velocity (SGV) on the enrichment ratio $\left(\mathrm{E}_{\mathrm{r}}\right)$ and percentage recovery $\left(R_{p}\right)$ of captopril in pure form aqueous solution with TDT- 


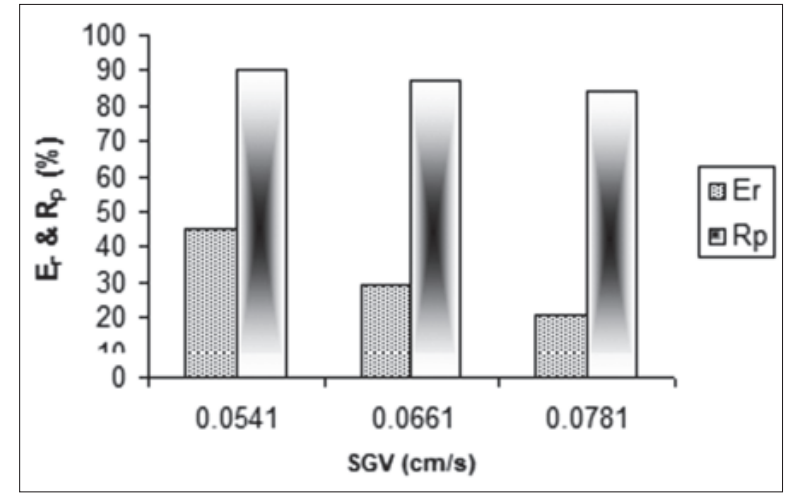

FIGURE 2.

TABLE 1. Effect of superficial gas velocity, $\mathrm{pH}$ of feed solution and collector-colligend ratio on the recovery and enrichment of captopril in pure form.

\begin{tabular}{ccccc}
$\begin{array}{c}\text { Concentration of } \\
\text { TDTMAB }(\mathbf{m M} / \mathbf{L})\end{array}$ & $\begin{array}{c}\mathbf{p H} \text { of the feed } \\
\text { solution }\end{array}$ & $\begin{array}{c}\text { SGV } \\
\mathbf{( c m} / \mathbf{s})\end{array}$ & $\begin{array}{c}\text { Percentage } \\
\text { recoverya }\end{array}$ & $\begin{array}{c}\text { Enrichment } \\
\text { ratiob }\end{array}$ \\
\hline 1 & 3.75 & 0.0541 & 70.93 & 35.4648 \\
1.5 & 3.75 & 0.0541 & 84.61 & 42.3048 \\
2 & 1.50 & 0.0541 & 72.10 & 36.0520 \\
2 & 2.25 & 0.0541 & 81.81 & 40.9066 \\
2 & 3.00 & 0.0541 & 87.35 & 43.6726 \\
2 & 3.75 & 0.0541 & 90.21 & 45.1082 \\
2 & 3.75 & 0.0661 & 86.97 & 28.9900 \\
2 & 3.75 & 0.0781 & 84.06 & 21.0156 \\
2.5 & 3.75 & 0.0541 & 91.11 & 45.5560 \\
\hline
\end{tabular}

aAter 120 min of operation.

bWhen $\mathrm{Ci}=0.5 \mathrm{mM} / \mathrm{L}$, feed volume $=100 \mathrm{ml}$, column height $=65 \mathrm{~cm}$.

TABLE 2. Effect of colligend concentration on the recovery and enrichment of captopril in pure form.

\begin{tabular}{ccc}
\hline $\mathbf{C i}(\mathbf{m M})$ & Percentage recoverya $^{\mathbf{a}}$ & Enrichment ratio $^{\mathbf{b}}$ \\
\hline 0.5 & 90.21 & 45.1082 \\
0.75 & 82.16 & 41.0800 \\
1 & 61.22 & 30.6112 \\
1.25 & 58.88 & 29.4424 \\
\hline
\end{tabular}

aAfter 120 min of operation.

bWhen concentration of TDTMAB $=2 \mathrm{mM} / \mathrm{L}, \mathrm{pH}$ of feed solution $=3.75$,

$\mathrm{SGV}=0.0541 \mathrm{~cm} / \mathrm{s}$, feed volume $=100 \mathrm{ml}$, column height $=65 \mathrm{~cm}$.

MAB. The results indicate that the values of enrichment ratio $\left(E_{r}\right)$ and percentage recovery $\left(R_{p}\right)$ of captopril in pure form decreased with the increasing of superficial gas velocity (SGV). Enrichment ratio and percentage recovery of captopril in pure form were found higher when superficial gas velocity (SGV) was $0.0541 \mathrm{~cm} / \mathrm{s}$ in comparison to that of SGV 0.0661, 0.0781 $\mathrm{cm} / \mathrm{s}$. Amount of adsorbed material on the surface of the gas bubble depends on residence time of gas bubble in solution which in turn depends on low gas velocity. At SGV $=0.0541$ $\mathrm{cm} / \mathrm{s}, 90.21 \%$ of captopril in pure form is transferred into the foam with the help of TDTMAB (when Time $=120$ mins, $\varphi=$ $4, \mathrm{pH}=3.75, \mathrm{C}_{\mathrm{i}}=0.5 \mathrm{mmole} / \mathrm{L}$, Feed volume $=100 \mathrm{~mL}$, column height $=65 \mathrm{~cm})$.

Figure 3 shows the effect of feed $\mathrm{pH}$ on the enrichment ratio $\left(E_{r}\right)$ and percentage recovery $\left(R_{p}\right)$ of captopril in pure form

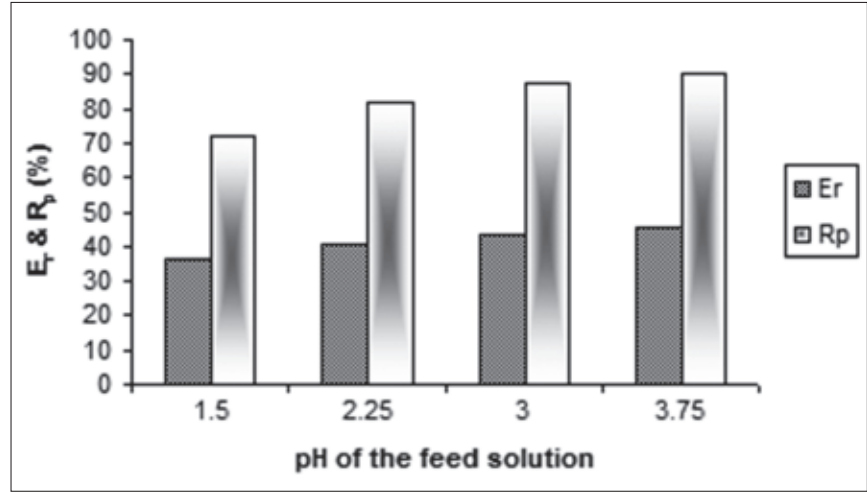

FIGURE 3.

from aqueous solution. Enrichment ratio and percentage recovery of captopril in pure form were found higher when $\mathrm{pH}$ of feed was 3.75 in comparison to that of $\mathrm{pH} 1.5,2.25$ and 3. When $\mathrm{pH}$ of the feed solution is too low, the percentage recovery of captopril in pure form is less as because foam is less stable.

The main parameter was the collector-colligend ratio $(\varphi)$. The collector alone cannot be flotated, but the collector captopril complex can. Figure 4 (Table 1) shows the effect of collector -colligend ratio $(\varphi)$ on the enrichment ratio $\left(E_{r}\right)$ and percentage recovery $\left(R_{p}\right)$ of captopril in pure form from aqueous solution. Percentage recovery of pure captopril was 90.21 with TDTMAB at $\varphi=4$, provided time $=120$ mins, SGV $=0.0541$ $\mathrm{cm} / \mathrm{s}$ and $\mathrm{pH}=3.75$. At $\varphi=5$, percentage recovery of captopril in pure form with TDTMAB was almost similar (91.11\%) to the recovery at $\varphi=4$.

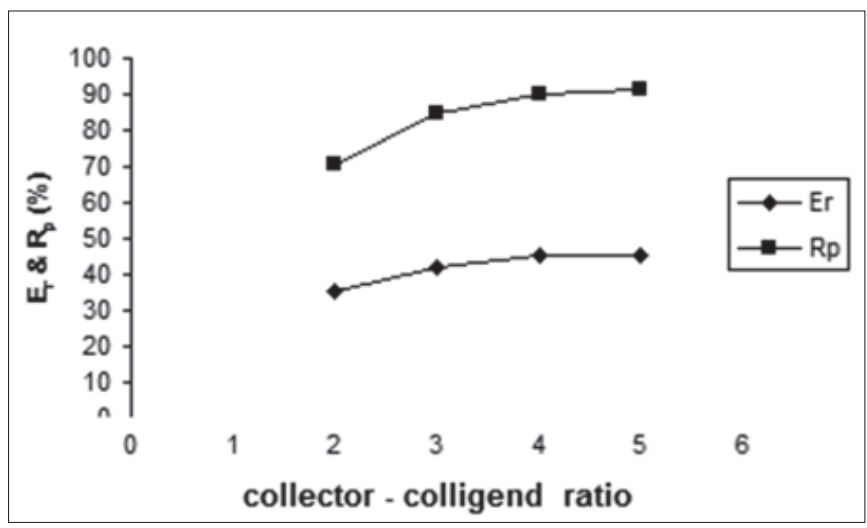

FIGURE 4.

Figure 5 (Table 2) shows the effect of colligend concentration on enrichment ratio $\left(E_{r}\right)$ and percentage recovery $\left(R_{p}\right)$ of captopril in pure form from aqueous solution at $\mathrm{pH}=3.75$. The results indicate that the enrichment ratio and percentage recovery of captopril in pure form decreases with the increasing concentration of the colligend. $E_{r} \& R_{p}$ values of captopril in pure form were found higher when colligend concentration was $0.5 \mathrm{mmole} / \mathrm{L}$ in comparison to that of $0.75,1$ and 1.25 $\mathrm{mmole} / \mathrm{L}$. This foam fractionation method is very much effective at lower concentration of feed. 


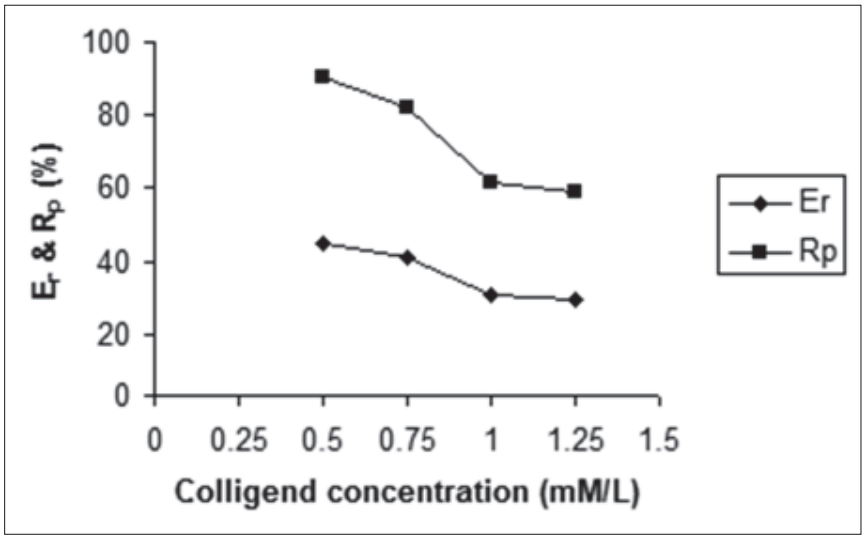

FIGURE 5.

Figure 6 (Table 3) shows the effect of feed volume on the enrichment ratio and percentage recovery of captopril in pure form from aqueous solution with TDTMAB at $\mathrm{pH}=3.75$. The results indicate that the enrichment ratio and percentage recovery decreases with the increasing feed volume. When feed volume is less, in that case there is a sufficient foam height inside the column, and it provides dry foam, therefore enrichment ratio and the percentage recovery is high.

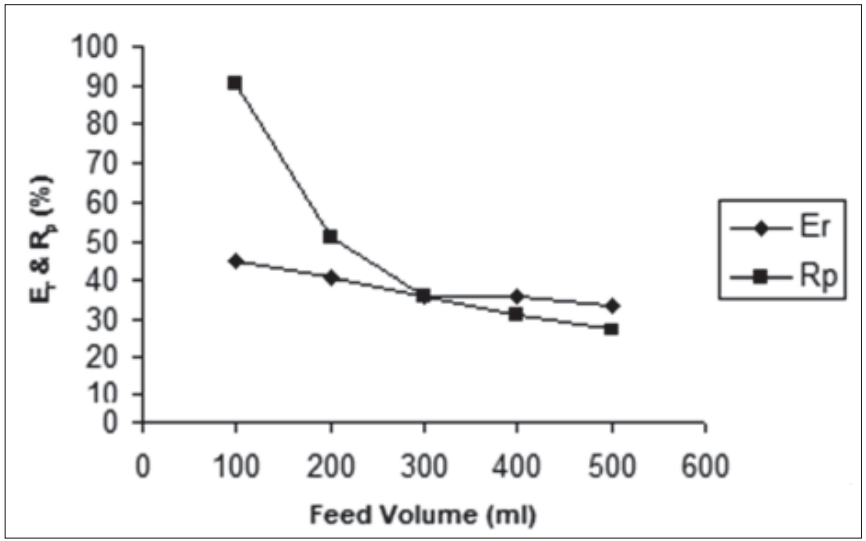

FIGURE 6.

TABLE 3. Effect of feed volume on the recovery and enrichment of captopril in pure form.

\begin{tabular}{ccc}
\hline Feed volume $(\mathbf{m l})$ & Percentage recoverya $^{\mathbf{a}}$ & Enrichment ratio $^{\mathbf{b}}$ \\
\hline 100 & 90.21 & 45.1082 \\
200 & 50.93 & 40.7418 \\
300 & 36.01 & 36.0074 \\
400 & 31.23 & 35.6946 \\
500 & 26.76 & 33.4460 \\
\hline
\end{tabular}

aAfter 120 min of operation.

bWhen concentration of TDTMAB $=2 \mathrm{mM} / \mathrm{L}$, $\mathrm{pH}$ of feed solution $=3.75$,

$\mathrm{SGV}=0.0541 \mathrm{~cm} / \mathrm{s}, \mathrm{Ci}=0.5 \mathrm{mM} / \mathrm{L}$, column height $=65 \mathrm{~cm}$.

As it is shown in Figure 7 (Table 4), the enrichment ratio and percentage recovery of captopril in pure form increases as the column height increases, presumably due to the development of dry foam with the increasing column height.

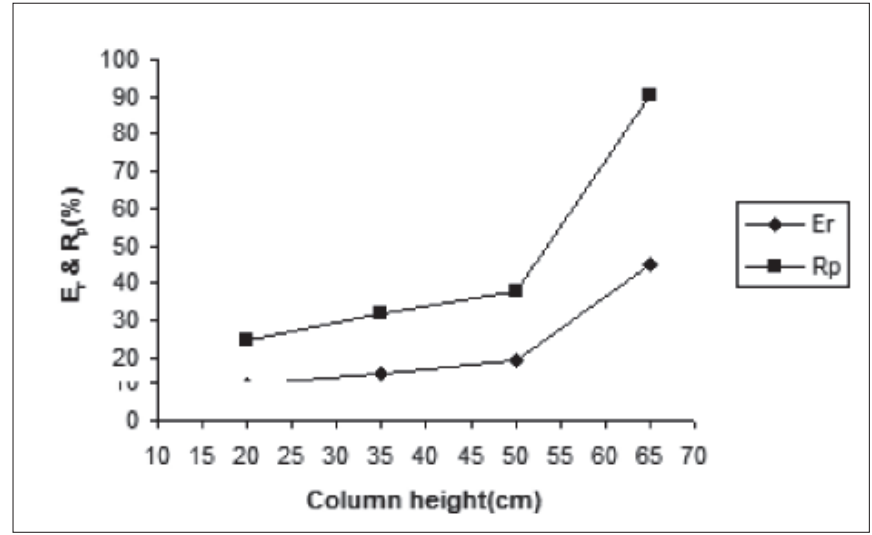

FIGURE 7.

TABLE 4. Effect of column height on the recovery and enrichment of captopril in pure form.

\begin{tabular}{ccc}
\hline Column height $\mathbf{( c m )}$ & Percentage recoverya & Enrichment ratio $^{\mathbf{b}}$ \\
\hline 20 & 24.67 & 12.3383 \\
35 & 31.58 & 15.7880 \\
50 & 37.83 & 18.9148 \\
65 & 90.21 & 45.1082 \\
\hline
\end{tabular}

aAfter 120 min of operation.

bWhen concentration of TDTMAB $=2 \mathrm{mmole} / \mathrm{L}, \mathrm{pH}$ of feed solution $=3.75$

$\mathrm{SGV}=0.0541 \mathrm{~cm} / \mathrm{s}, \mathrm{Ci}=0.5 \mathrm{mmole} / \mathrm{L}$, feed volume $=100 \mathrm{ml}$, column height $=65 \mathrm{~cm}$.

TABLE 5. Effect of aliphatic chain length of the collector on the recovery and enrichment of captopril.

\begin{tabular}{|c|c|c|c|c|}
\hline & \multirow{2}{*}{$\begin{array}{l}\text { Concentration } \\
\text { of SAA (mM/L) }\end{array}$} & \multirow[b]{2}{*}{$\begin{array}{l}\text { Captopril in } \\
\text { formulation }\end{array}$} & \multicolumn{2}{|c|}{ Enrichment ratiob } \\
\hline & & & $\begin{array}{l}\text { Captopril in } \\
\text { pure form }\end{array}$ & $\begin{array}{l}\text { Captopril in } \\
\text { formulation }\end{array}$ \\
\hline SAA, TDTMAB & 2 & 81.66 & 45.1082 & 40.8312 \\
\hline SAA, HDTMAB & 2 & 73.9 & 41.9256 & 36.9524 \\
\hline
\end{tabular}

The results (Table 5) indicate that the percentage recovery of captopril in formulation was lower as compared to captopril in pure form from aqueous solution at $\varphi=4$. This is probably because of the presence of other soluble ingredients, which decreases the enrichment of captopril in formulation. As it is shown in Table 5 percentage recovery of captopril in pure form with TDTMAB (MW=336.40 g/mole) was higher as compare to HDTMAB (MW $=364.46 \mathrm{~g} / \mathrm{mole}$ ) at $\varphi=4$. Since the tendency of the collector to adsorb on the interface depends on the length of its aliphatic chain, investigation were carried out with quaternary ammonia salts, $\mathrm{RMe}_{3} \mathrm{NBr}$, where the aliphatic chain $\mathrm{R}$ consists of 14 and 16C- atoms. The longer the alkyl residue $R$, the lower the captopril concentration in the foam liquid. The results indicate that the lower the molecular weight of the surface-active agent gives higher percentage recovery.

\section{CONCLUSIONS}

It is concluded that the experimental variables of SGV $=0.0541$ $\mathrm{cm} / \mathrm{s}, \mathrm{pH}=3.75, \varphi=4, \mathrm{C}_{\mathrm{i}}=0.5 \mathrm{mmole} / \mathrm{L}$, column height $=$ $65 \mathrm{~cm}$ gives highest percentage recovery of captopril from an aqueous solution by the foam fractionation method. It is also 
concluded that for $100 \mathrm{ml}$ feed volume, $90.21 \%$ of captopril recovered with TDTMAB at SGV=0.0541 cm $/ \mathrm{s}$ (when $\varphi=4$ ). The results also proved that low molecular weight \& moderate chain length of surface-active agent (tertadecyl trimethyl ammonium bromide) gives maximum percentage recovery of captopril than with hexadecyl trimethyl ammonium bromide. It is suggested that the removal amount can be enhanced by increasing the height of the liquid column and column height and adding more SAA initial and at intervals.

\author{
Nomenclature \\ SGV superficial gas velocity $(\mathrm{cm} / \mathrm{s})$ \\ $\varphi \quad$ collector-colligend ratio \\ $R_{p} \quad$ percentage recovery \\ $\mathrm{E}_{\mathrm{r}} \quad$ enrichment ratio \\ ACE angiotensin-converting enzyme \\ $\mathrm{CMC}$ critical micelle concentration (mM/L) \\ $\mathrm{C}_{\mathrm{f}} \quad$ concentration of drug in the foam (mM/L) \\ $\mathrm{C}_{\mathrm{i}} \quad$ concentration of drug in the feed (mM/L) surfactant
}

\section{Kaptopril'in köpük parçalanması yöntemi ile geri kazanımı}

ÖZET: Atık sularda bulunan farmasötik ürünler nedeniyle açığa çıkan toksik etkiler; günümüzde çevre kirliliğini oluşturan faktörlerin en önemlilerinden biri olarak kabul edilmektedir. Bu çalışma kapsamında, seyreltik sulu çözeltiler içinden kaptopril'in geri kazanımını sağlayabilmek için köpük parçalanması yöntem uygunluğu araştırılmıştır. Bu amaçla hazırlanan iki çözeltiden birinin kaptopril’i saf ilaç etken maddesi olarak içerirken diğer çözeltinin kaptopril içeren tabletlerden hareketle hazırlandığı bildirilmiştir. Kaptopril, antihipertansif etki gösteren anyonik bir bileşiktir ve bu özellikleri nedeniyle akuatik toksisiteye neden olabileceği düşünülmektedir. Geri kazanım yeterliliğinin ölçüsü olarak; gaz hızı işlevi, hazırlanan besleme çözeltilerinin pH'ı, yüzey aktif madde-ilaç etken maddesi oranı (j), ilaç etken madde derişimi, hazırlanan besleme çözeltilerinin hacmi, kolon yüksekliği, yüzey aktif maddenin taşıdığı alifatik zincirin uzunluğu gibi parametreler incelenmiş ve optimum koşullar belirlenmiştir. Saf ilaç etken maddesi için geri kazanım yüzdesi \%90, pH değeri 3.75, en uygun gaz hızı şartlarında j değeri 4 olarak tespit edilmiştir. Gaz hızının, besleme hacmine bağlı olduğu bildirilmiştir. Geri kazanım oranının (Rp) alkil zinciri uzadıkça düştüğü tespit edilmiştir. Zenginleştirme oranının (Er) kolondaki köpük yüksekliğinin artışıyla doğru orantılı olarak yükseldiği tespit edilmiştir. Rp ve Er değerleri; kaptopril içeren tabletler için, saf ilaç etken maddesi ile kıyaslandığında daha düşük bulunmuştur.

ANAHTAR KELIMELER: köpük parçalanması yöntemi; kaptopril; yüzey aktif madde-ilaç etken maddesi oranı; yüzde geri kazanım; zenginleştirme oranı

\section{REFERENCES}

1. Martindale. The Extra Pharmacopoeia, Thirty first ed., Royal Pharmaceutical Society, London, 1996, pp. 838.

2. Tripathi KD. Essentials of Medical Pharmacology, Fifth ed Jaypee Brothers Medical Publishers (P) Ltd., New Delhi. 2003.

3. Lemlich R. Adsorptive Bubble Separation Technique. Academic press, New York. 1972.

4. Uraizee F, Narsimhan G. Foam fractionation of proteins and enzymes-II. Performance and modeling. Enzyme Microb Technol 1990; 12: 315-6.

5. Brown AK, Kaul A, Varley J. Continuous foaming for protein recovery I. Recovery of b-casein. Biotechnol Bioeng 1999; 62: 278-90.

6. Clarke AN, Wilson DJ. Foam Flotation: Theory and Applications. Marcel Dekker Inc., New York and Basel. 1983.

7. Schweitzer PA. Handbook of Separation Techniques for Chemical Engineers. Mc. Graw -Hill Inc., USA. 1979.
8. Lockwood CE, Jay M, Bummer PM. Foam fractionation of binary mixtures of lysozyme and albumin. J Pharm Sci 2000; 89: 693-704.

9. Saleh ZS, Hossain MdM. A study of the separation of proteins from multicomponent mixtures by a semi-batch foaming process. Chemical Engineering and Processing 2001; 40: 371-8.

10. Akira Suzuki, Kazuki Yasuhara, Hideshi Seki, Hideo Maruyama. Selective Foam Separation of binary protein solution by SDS complexation method. J Colloid Interface Sci 2002; 253: 402-8.

11. Sonc A, Grilc V. Batch foam fractionation of surfactants from aqueous solutions. Acta Chim Solv 2004; 51: 687-98.

12. Gehle RD, Schugerl K. Penicillin recovery from aqueous solutions by continuous foam flotation. Appl Microbiol Biotechnol 1984; 19:3 73-5.

13. Nalecz-Jawecki G, Persoone G. Toxicity of Selected pharmaceuticals to the Anostracan Crustacean Thamnocephalus platyurus, Environ Sci \& Pollut Res 2006; 13: 22-7.

14. Indian Pharmacopoeia, Vol. 1 , Controller of Publication, Civil lines Delhi - 110054, 1996. 